\title{
Problematika Penegakan Disiplin Terhadap Pegawai Negeri Sipil Yang Tidak Melaksanakan Putusan Pengadilan Terkait Biaya Penghidupan Anak Dan Mantan Istri
}

\author{
Novendia Dara Cintaanito \\ Magister Ilmu Hukum, Universitas Indonesia \\ Email: ndcintaanito@gmail.com
}

\begin{tabular}{l}
\hline Article Info \\
Article history: \\
Article Received: June 222021 \\
Publication: July 08 2021 \\
\hline
\end{tabular}

\section{Keywords:}

Disiplin; Pegawai Negeri

Sipil; Penghidupan;

Perceraian

\begin{abstract}
Abstrak
Dalam rangka mewujudkan Pegawai Negeri Sipil yang handal, profesional, dan bermoral sebagai penyelenggara pemerintahan yang menerapkan prinsip-prinsip kepemerintahan yang baik (good governance), maka Pegawai Negeri Sipil sebagai unsur aparatur negara dituntut untuk setia kepada Pancasila, Undang-Undang Dasar Negara Republik Indonesia Tahun 1945, Negara Kesatuan Republik Indonesia, dan Pemerintah, bersikap disiplin, jujur, adil, transparan, dan akuntabel dalam melaksanakan tugas. Adanya tindakan Pegawai Negeri Sipil (pria) yang tidak memenuhi kewajiban sebagaimana yang diputuskan oleh hakim dengan tidak memberikan nafkah kepada anak dan mantan istri setiap bulannya sebesar yang telah diputuskan menjadi menarik untuk dibahas mengingat hal tersebut berkaitan erat dengan hajar hidup dari anak dan mantan isterinya. Dalam penelitian ini, penulis menggunakan metode penelitian metode penelitian library research atau penelitian kepustakaan. Mengenai penelitian semacam ini lazimnya juga disebut "Legal Research" atau "Legal Research Instruction".Dari hasil pembahasan diperoleh kesimpulan bahwa pertama, upaya yang dapat dilakukan Pejabat (Atasan) dari instansi tempat Pegawai Negeri Sipil (pria) bekerja atas tuntutan dari mantan istri guna pemenuhan putusan pengadilan adalah dengan memerintahkan kepada Bendahara instansi untuk melakukan pembagian gaji Pegawai Negeri Sipil (pria) bersangkutan sesuai dengan putusan pengadilan. Selanjutnya bendahara instansi dapat memberikan pembagian gaji yang menjadi hak mantan istri dan anaknya kepada mantan istri atau yang dikuasakannya secara langsung. Kedua, Suami tidak dapat menolak untuk memberikan pembagian gaji, karena sesuai dengan peraturan yang ada bahwa Pegawai Negeri Sipil (pria) yang menceraikan istrinya wajib melakukan pembagian gaji. Pasal 16 PP Izin Perkawinan Dan Perceraian Bagi Pegawai Negeri Sipil jo. Bab VIII angka 3 Surat Edaran No.48/SE/1990 secara tegas telah mengatur sanksi bagi Pegawai Negeri Sipil yang menolak melaksanakan ketentuan pembagian gaji pasca perceraian berupa salah satu hukuman disiplin berat sebagaimana yang diatur di dalam PP Disiplin PNS.

This is an open access article under the Lisensi Creative Commons Atribusi-BerbagiSerupa 4.0 Internasional
\end{abstract}

Corresponding Author:

Novendia Dara Cintaanito

Magister Ilmu Hukum, Universitas Indonesia

Email: ndcintaanito@gmail.com

\section{PENDAHULUAN}

\subsection{Latar Belakang}

Perkawinan ialah ikatan lahir batin antara seorang pria dengan seorang wanita sebagai suami istri dengan tujuan membentuk keluarga (rumah tangga) yang bahagia dan kekal berdasarkan Ketuhanan Yang Maha Esa. Perkawinan yang dikehendaki oleh Undang-Undang Nomor 1 Tahun 1974 tentang Perkawinan (selanjutnya disebut UU Perkawinan) ialah perkawinan yang menuju pada pembentukan suatu keluarga/rumah tangga yang bahagia dan kekal berdasarkan ketuhanan Yang Maha Esa. Dalam bahasa umum lazim dinamakan membentuk keluarga yang sakinah mawadah warahmah, penuh dengan kedamaian dan limpahan kasih sayang. 
Tujuan pernikahan adalah membentuk keluarga yang bahagia dan kekal. Oleh karenanya rasa saling toleransi, saling melengkapi satu sama lain haruslah senantiasa tercipta dalam rumah tangga. Membentuk keluarga yang diawali dengan perkawinan merupakan keinginan yang normal pada setiap manusia, karena perkawinan merupakan mekanisme survival (cara mempertahankan kelangsungan hidup). Melalui perkawinan akan diperoleh keturunan yang kemudian menjadi manusia-manusia baru yang akan mempertahankan kehadiran manusia di dunia dan akan hidup dalam kelompok-kelompok masyarakat. Perkawinan juga untuk membentuk suatu rumah tangga dimana keluarga dalam rumah tangga dapat terlaksana secara damai dan tenteram serta kekal dengan disertai rasa kasih sayang antara suami istri.

Menjalani rumah tangga tidak selamanya lancar, suatu saat akan timbul suatu perselisihan. Perselisihan tersebut terkadang dapat didamaikan namun terkadang ada pula perselisihan yang tidak dapat didamaikan sehingga terjadi suatu perceraian. Menurut Subekti bahwa perceraian merupakan penghapusan perkawinan dengan putusan hakim, atau merupakan tuntutan salah satu pihak dalam perkawinan itu. Dalam UU Perkawinan juga telah ditegaskan bahwa putusnya perkawinan disebabkan oleh tiga faktor yaitu, kematian, perceraian, dan karena putusan hakim, dengan demikian perceraian merupakan salah satu faktor penyebab putusnya perkawinan.

Terjadinya perceraian ini akan menimbulkan akibat hukum, baik terhadap suami ataupun istri yang ditinggalkan, anak maupun terhadap harta benda dalam perkawinan. Dari akibat hukum tersebut, maka yang sering menjadi persengketaan bagi para pihak adalah mengenai harta benda dalam perkawinan yang berwujud harta bersama, dan hak asuh atas anak yang dilahirkan dari perkawinan mereka.

Dalam rangka pelaksanaan UU Perkawinan, khususnya untuk kelompok warga negara Indonesia yang berstatus Pegawai Negeri Sipil, oleh pemerintah pada tanggal 21 April 1983 telah diterbitkan suatu peraturan yaitu Peraturan Pemerintah Nomor 10 Tahun 1983 tentang Izin Perkawinan dan Perceraian bagi Pegawai Negeri Sipil yang selanjutnya dirubah oleh Peraturan Pemerintah Nomor 45 Tahun 1990 tentang Perubahan atas Peraturan Pemerintah Nomor 10 Tahun 1983 tentang Izin Perkawinan dan Perceraian Bagi Pegawai Negeri Sipil (selanjutnya disebut PP Izin Perkawinan Dan Perceraian Bagi Pegawai Negeri Sipil). Dalam konsideransnya disebutkan bahwa, Pegawai Negeri Sipil wajib memberikan contoh yang baik bagi bawahannya dan menjadi teladan sebagai warga negara yang baik dalam masyarakat termasuk dalam menyelenggarakan kehidupan keluarga.

Dengan adanya PP Izin Perkawinan Dan Perceraian Bagi Pegawai Negeri Sipil seakanakan membatasi bahkan menghalangi seorang Pegawai Negeri Sipil yang akan mempergunakan haknya untuk bercerai manakala rumah tangganya sudah tidak rukun/tidak harmonis lagi. PP Izin Perkawinan Dan Perceraian Bagi Pegawai Negeri Sipil mengatur bahwa Pegawai Negeri Sipil yang akan melakukan perceraian wajib memperoleh izin lebih dahulu dari pejabat. Permintaan untuk memperoleh izin tersebut diajukan secara tertulis dan harus dicantumkan alasan yang lengkap yang mendasari permintaan izin perceraian.

Ketentuan Pasal 7 ayat (3) PP Izin Perkawinan Dan Perceraian Bagi Pegawai Negeri Sipil mengatur bahwa Pejabat yang berwenang dapat menolak memberikan izin perceraian kepada PNS yang bersangkutan apabila:

1. bertentangan dengan ajaran/peraturan agama yang dianut Pegawai Negeri Sipil yang bersangkutan;

2. tidak ada alasan yang berdasar sesuai yang ditetapkan oleh peraturan perundang-undangan dan ketentuan-ketentuan dalam PP Izin Perkawinan Dan Perceraian Bagi Pegawai Negeri Sipil;

3. bertentangan dengan peraturan perundang-undangan yang berlaku; dan/atau

4. alasan yang dikemukakan bertentangan dengan akal sehat.

Selanjutnya, Pasal 8 ayat (1) PP Izin Perkawinan dan Perceraian bagi Pegawai Negeri Sipil mengatur bahwa apabila perceraian terjadi atas kehendak Pegawai Negeri Sipil (pria), 
maka Pegawai Negeri Sipil (pria) tersebut wajib menyerahkan sebagian gajinya untuk penghidupan bekas istri dan anak-anaknya. Pengaturan ini merupakan bentuk perlindungan hukum terhadap hak bekas istri dan anak-anak setelah terjadinya perceraian yang dikehendaki oleh Pegawai Negeri Sipil (pria).

Dalam rangka mewujudkan Pegawai Negeri Sipil yang handal, profesional, dan bermoral sebagai penyelenggara pemerintahan yang menerapkan prinsip-prinsip kepemerintahan yang baik (good governance), maka Pegawai Negeri Sipil sebagai unsur aparatur negara dituntut untuk setia kepada Pancasila, Undang-Undang Dasar Negara Republik Indonesia Tahun 1945, Negara Kesatuan Republik Indonesia, dan Pemerintah, bersikap disiplin, jujur, adil, transparan, dan akuntabel dalam melaksanakan tugas.

Untuk menumbuhkan sikap disiplin Pegawai Negeri Sipil, peraturan perundangundangan mengamanatkan ditetapkannya peraturan pemerintah mengenai disiplin Pegawai Negeri Sipil. Peraturan pemerintah mengenai disiplin PNS tersebut telah diatur dalam Peraturan Pemerintah Nomor 53 Tahun 2010 tentang Disiplin Pegawai Negeri Sipil (selanjutnya disebut PP Disiplin Pegawai Negeri Sipil).

Disiplin Pegawai Negeri Sipil adalah kesanggupan Pegawai Negeri Sipil untuk menaati kewajiban dan menghindari larangan yang ditentukan dalam peraturan perundang-undangan dan/atau peraturan kedinasan yang apabila tidak ditaati atau dilanggar dijatuhi hukuman disiplin. Penjatuhan hukuman disiplin dimaksudkan untuk membina PNS yang telah melakukan pelanggaran, agar yang bersangkutan mempunyai sikap menyesal dan berusaha tidak mengulangi dan memperbaiki diri pada masa yang akan datang.

Peraturan Disiplin Pegawai Negeri Sipil adalah peraturan yang mengatur mengenai kewajiban, larangan, dan sanksi apabila kewajiban tidak ditaati atau larangan dilanggar oleh Pegawai Negeri Sipil. Dalam PP Disiplin Pegawai Negeri Sipil secara tegas disebutkan jenis hukuman disiplin yang dapat dijatuhkan terhadap suatu pelanggaran disiplin. Penjatuhan hukuman berupa jenis hukuman disiplin ringan, sedang, atau berat sesuai dengan berat ringannya pelanggaran yang dilakukan oleh Pegawai Negeri Sipil yang bersangkutan, dengan mempertimbangkan latar belakang dan dampak dari pelanggaran yang dilakukan.

Menurut Malayu Hasibuan, penjatuhan sanksi terhadap Pegawai Negeri Sipil merupakan upaya pemerintah untuk meningkatkan disiplin aparatur negara dari beberapa aspek strategis, salah satunya dengan meningkatkan penyempurnaan prilaku manusia, sehingga diharapkan prilaku aparatur negara memiliki sifat tangguh, cerdas, terampil, mandiri, dan rasa kesetiakawanan, kerja keras, hemat, produktif, disiplin, serta berorientasi ke masa depan untuk menciptakan kehidupan yang lebih baik.

PP Disiplin Pegawai Negeri Sipil telah mengatur secara tegas jenis hukuman disiplin yang dapat dijatuhkan terhadap suatu pelanggaran disiplin. Hal ini dimaksudkan sebagai pedoman bagi pejabat yang berwenang menghukum serta memberikan kepastian dalam menjatuhkan hukuman disiplin. Penjatuhan hukuman baik hukuman ringan, sedang dan berat disesuaikan dengan pelanggaran yang dilakukan oleh Pegawai Negeri Sipil dengan mempertimbangkan latar belakang dan dampak dari pelanggaran yang dilakukan oleh Pegawai Negeri Sipil.

Berdasarkan kasus yang peneliti temukan, ditemukan kasus dimana seorang Pegawai Negeri Sipil (pria) yang telah bercerai dengan istrinya dan perceraian tersebut telah memperoleh putusan dari Pengadilan sebagaimana yang diputuskan dalam perkara Nomor: XX/Pdt.G/2020/PN.Jkt.Pst, yang mana dari putusan tersebut salah satu isinya memerintahkan kepada PNS pria bersangkutan untuk membayar nafkah kepada anak dan mantan istri setiap bulannya sebesar Rp. 4.133.300,00 (empat juta seratus tiga puluh tiga ribu tiga ratus rupiah). Namun Pegawai Negeri Sipil (pria) yang bersangkutan tidak memenuhi kewajiban sebagaimana yang diputuskan dengan tidak memberikan nafkah kepada anak dan mantan istri setiap bulannya sebesar yang telah diputuskan Hakim.

Tindakan Pegawai Negeri Sipil (pria) yang tidak memenuhi kewajiban sebagaimana yang diputuskan oleh hakim dengan tidak memberikan nafkah kepada anak dan mantan istri 
setiap bulannya sebesar yang telah diputuskan menimbulkan pertanyaan: Apakah Pegawai Negeri Sipil (pria) yang bersangkutan boleh untuk mengabaikan putusan pengadilan? Bagaimanakah penegakan disiplin bagi Pegawai Negeri Sipil (pria) yang bersangkutan? Dalam Penelitan ini, Peneliti akan melakukan penelitian lebih lanjut atas permasalahan yang timbul tersebut.

Berdasarkan permasahan-permasalahan tersebut di atas, Peneliti tertarik untuk melakukan penelitian dengan judul:

"Penegakan Disiplin Bagi Pegawai Negeri Sipil (Pria) Yang Tidak Melaksanakan Putusan Pengadilan Terkait Biaya Penghidupan Anak Dan Mantan Istri Akibat Perceraian."

\subsection{Rumusan Masalah}

Berdasarkan uraian latar belakang diatas, maka yang menjadi rumusan masalah pada penelitian ini adalah:

1. Bagaimana upaya yang dapat dilakukan Pejabat (Atasan) dari instansi tempat Pegawai Negeri Sipil (pria) bekerja atas tuntutan dari mantan istri guna pemenuhan putusan pengadilan?

2. Bagaimana penegakan disiplin bagi Pegawai Negeri Sipil (pria) yang tidak melaksanakan putusan pengadilan terkait biaya penghidupan anak dan mantan istri akibat perceraian?

\subsection{Tujuan dan Manfaat Penelitian}

\subsubsection{Tujuan Penelitian}

Adapun tujuan dari penelitian ini adalah sebagai berikut:

a. Untuk menjelaskan upaya yang dapat dilakukan Pejabat (Atasan) dari instansi tempat Pegawai Negeri Sipil (pria) bekerja atas tuntutan dari mantan istri guna pemenuhan putusan pengadilan

b. Untuk menjelaskan penegakan disiplin bagi Pegawai Negeri Sipil (pria) yang tidak melaksanakan putusan pengadilan terkait biaya penghidupan anak dan mantan istri akibat perceraian.

\subsubsection{Manfaat Penelitian}

Adapun manfaat dari penelitian ini adalah sebagai berikut:

a. Manfaat Teoretis

Penelitian ini bermanfaat dalam kajian ilmu hukum mengenai penegakan disiplin bagi Pegawai Negeri Sipil yang tidak melaksanakan putusan pengadilan terkait biaya penghidupan anak dan mantan istri akibat perceraian.

b. Manfaat Praktis

Penelitian ini diharapkan memberikan manfaat untuk Kementerian Pendayagunaan Aparatur Negara dan Reformasi Birokrasi. Hal ini juga diharapkan menjadi bahan pertimbangan dan masukkan bagi pemerintah dan lembaga legislatif untuk melakukan penyempurnaan terhadap ketentuan Peraturan Disiplin PNS, khususnya Peraturan Pemerintah Nomor 53 Tahun 2010 tentang Disiplin Pegawai Negeri Sipil.

\section{METODE PENELITIAN}

\subsection{Bentuk Penelitian}

Penelitian ini merupakan penelitian yuridis empiris, yaitu jenis penelitian hukum sosiologis dan dapat pula disebut dengan penelitian lapangan yaitu mengkaji ketentuan hukum yang berlaku serta apa yang terjadi dalam kenyataan di masyarakat.

\subsection{Pendekatan Penelitian}

Sesuai dengan jenis penelitiannnya yakni penelitian hukum normatif (yuridis normatif), maka dapat digunakan lebih dari satu pendekatan. Dalam penelitian ini digunakan pendekatan perundang-undangan (Statute Approach) dan pendekatan konsep (conceptual approach). 


\subsection{Jenis Data} sekunder.

Jenis data yang digunakan di dalam penelitian ini diambil dari data primer dan data

a. Primer adalah data yang diperoleh secara langsung dari sumber pertama yang terkait dengan permasalahan yang akan dibahas. Sumber data diperoleh dari lapangan secara langsung dengan wawancara kepada Kedeputian Bidang SDM Aparatur Kementerian Pendayagunaan Aparatur Negara dan Reformasi Birokrasi. Bahan hukum primer yang digunakan antara lain:

1) Undang-undang Dasar Republik Indonesia 1945;

2) Undang-Undang Nomor 1 Tahun 1974 tentang Perkawinan

3) Undang-Undang Nomor 5 Tahun 2014 tentang Aparatur Sipil Negara

4) Peraturan Pemerintah Nomor 10 Tahun 1983 tentang Izin Perkawinan dan Perceraian bagi Pegawai Negeri Sipil dan Peraturan Pemerintah Nomor 45 Tahun 1990 tentang Perubahan atas Peraturan Pemerintah Nomor 10 Tahun 1983 tentang Izin Perkawinan dan Perceraian bagi Pegawai Negeri Sipil

5) Peraturan Pemerintah Nomor 53 Tahun 2010 tentang Disiplin Pegawai Negeri Sipil

6) Surat Edaran Nomor 48/SE/1990 tentang Petunjuk Pelaksanaan PP Izin Perkawinan dan Perceraian bagi Pegawai Negeri Sipil

b. Data sekunder adalah data-data yang diperoleh dari buku-buku sebagai data pelengkap sumber data primer. Sumber data sekunder penelitian ini adalah data-data yang diperoleh dengan melakukan kajian pustaka seperti buku-buku ilmiah, hasil penelitian dan sebagainya.

\subsection{Metode Analisis Data}

Metode yang digunakan adalah metode kualitatif yang kemudian disusun secara sistematis. Data yang diperoleh baik dari studi lapangan maupun studi dokumen, pada dasarnya merupakan data tataran yang dianalisis secara deskriptif kualitatif, yaitu setelah data terkumpul kemudian dituangkan dalam bentuk uraian logis dan sistematis, selanjutnya dianalisis untuk memperoleh kejelasan penyelesaian masalah, kemudian ditarik kesimpulan secara deduktif, yaitu dari hal yang bersifat umum menuju hal yang bersifat khusus. Data yang telah diperoleh disusun secara sistematis kemudian dianalisis secara kualitatif guna mendapatkan kejelasan tentang masalah yang akan dibahas. Tujuan dari analisis tersebut adalah untuk mendapatkan gambaran mengenai perlindungan hukum terhadap anak yang lahir dari perkawinan campuran yang tidak tercatat.

\section{HASIL DAN PEMBAHASAN}

\subsection{Kasus Posisi}

Penulis akan menganalisis kasus perceraian Pegawai Negeri Sipil sebagaimana dalam perkara di Pengadilan Negeri Jakarta Pusat dengan register Nomor: XX/Pdt.G/2020/PN. Jkt.Pst.

Pada tahun YY, AA (nama disamarkan) dan BB (nama disamarkan) telah melangsungan perkawinan secara agama XX dan telah dicatatkan pada Kantor Catatan Sipil XX, sehingga dengan demikian mereka adalah suami isteri yang sah. Dari perkawinan tersebut telah dikaruniai anak yakni CC (nama disamarkan). AA merupakan seorang Pegawai Negeri Sipil (PNS) pada XX.

AA menggugat cerai BB dengan mengajukan gugatan pada tanggal 14 Januari 2020 dan telah diterima dan didaftarkan di Kepaniteraan Pengadilan Negeri Jakarta Pusat dengan Register Nomor: XX/Pdt.G/2020/PN. Jkt.Pst.

Penggugat mengajukan gugatan kepada Tergugat dikarenakan terjadi perselisihanperselisihan dan pertengkaran-pertengkaran yang disebabkan karena kurang berkomunikasi serta Tergugat yang dinilai Penggugat tidak dapat menahan emosinya yang menimbulkan permasalahan berkepanjangan. 
Bahwa pertengkaran antara Penggugat dan Tergugat telah terjadi secara terus-menerus dan berlarut-larut sehingga diantara Penggugat dan Tergugat tidak ada harapan untuk hidup rukun lagi dalam rumah tangga, sehingga terpenuhi Pasal 19 (f) Peraturan Pemerintah Republik Indonesia Nomor 9 Tahun 1975 tentang Pelaksanaan Undang- Undang Nomor 1 Tahun 1974 tentang perkawinan yang berbunyi "antara suami dan istri terus menerus terjadi perselisihan dan pertengkatan dan tidak ada harapan untuk hidup rukun lagi dalam rumah tangga.

Selanjutnya Majelis Hakim dalam putusannya menjatuhkan amar sebagai berikut:

\section{MENGADILI}

1) Mengabulkan gugatan Penggugat seluruhnya

2) Menyatakan perkawinan antara Penggugat dan Tergugat yang dilangsungkan secara agama XX pada tanggal DD MM YY bertempat di XX, sesuai dengan Kutipan Akta Perkawinan Nomor XXX tanggal DD MM YY, putus karena perceraian dengan segala akibat hukumnya;

3) Menyatakan bahwa hak asuh anak yang lahir dari perkawinan antara lahir di XX pada tanggal DD MM YY, berada Penggugat dengan Tergugat yang bernama CC, pada pihak Tergugat;

4) Penggugat untuk membayar nafkah yaitu sebesar $1 / 3$ gaji untuk anak sampai dengan anak dewasa dan $1 / 3$ gaji lagi untuk Tergugat sampai dengan Tergugat menikah lagi sebagaimana ketentuan peraturan dan perundang-undangan tentang lzin Perkawinan dan Perceraian bagi Pegawai Negeri Sipil setiap bulannya sebesar Rp. 4.133 .300 (empat juta seratus tiga puluh tiga ribu tiga ratus rupiah);

5) Dst.

\subsection{Upaya Yang Dapat Dilakukan Pejabat (Atasan) Dari Instansi Tempat Pegawai Negeri Sipil (Pria) Bekerja Atas Tuntutan Dari Mantan Istri Guna Pemenuhan Putusan Pengadilan}

Perceraian adalah suatu malapetaka, akan tetapi perceraian dalam suatu perkawinan walaupun termasuk perbuatan yang harus dihindarkan bahkan merupakan salah satu perbuatan yang paling dibenci Tuhan, tidak dapat dihindarkan bahkan harus dilakukan karena perceraian adalah suatu malapetaka yang harus dilampaui untuk dapat menghindari malapetaka berikutnya yang lebih besar lagi.

Pada dasarnya suatu perkawinan itu harus berlangsung kekal dan hanya putus karena kematian akan tetapi pada kenyataannya putusnya perkawinan itu bukan hanya disebabkan oleh adanya kematian dari salah satu pihak tetapi ada hal-hal atau alasan-alasan lain yang menyebabkannya. Pasal 38 UU Perkawinan menentukan bahwa perkawinan dapat putus karena kematian, perceraian dan atas putusan pengadilan.

UU Perkawinan tidak mengatur mengenai putusnya perkawinan karena kematian. UU hanya menyinggung mengenai putusnya perkawinan karena kematian pada Pasal 38 UU Perkawinan dimana disebutkan bahwa perkawinan putus karena kematian. Perkawinan antara suami istri putus, yang dimaksud adalah "apabila perkawinan tersebut berakhir", dan berakhirnya perkawinan itu bisa karena perceraian, demikian pula bisa karena kematian salah seorang suami atau istri, atau karena keputusan pengadilan.

Perceraian hanya dibenarkan penggunaannya dalam keadaan darurat agar tidak menimbulkan kerugian yang lebih besar. Dapat dikatakan bahwa perceraian adalah pintu daruratnya sebuah perkawinan guna keselamatan bersama. Sehingga terdapat peraturanperaturan perceraian di samping peraturan mengenai perkawinan, dan atas dasar itu pulalah negara Indonesia mengatur hal-hal yang tidak diatur hukumnya dalam agama tentang perceraian di samping perkawinan, demi terciptanya kebahagiaan, kesejahteraan, dan ketentraman keluarga, masyarakat dan negara.

Pada umumnya perceraian harus memiliki cukup alasan untuk diajukan, tidak terkecuali perceraian bagi Pegawai Negeri Sipil. Perceraian Pegawai Negeri Sipil lebih dikhususkan karena terdapat peraturan yang khusus mengatur mengenai pernikahan dan 
perceraian bagi Pegawai Negeri Sipil yakni PP Izin Perkawinan Dan Perceraian Bagi Pegawai Negeri Sipil, serta Surat Surat Edaran Nomor 48/SE/1990.

Hubungan antara UU Perkawinan dengan PP Izin Perkawinan Dan Perceraian Bagi Pegawai Negeri Sipil dan Surat Surat Edaran Nomor 48/SE/1990 adalah PP Izin Perkawinan Dan Perceraian Bagi Pegawai Negeri Sipil dan Surat Surat Edaran Nomor 48/SE/1990 hanya mengatur tentang izin perkawinan dan perceraian, sedangkan mengenai ketentuan-ketentuan lainnya, misalnya tentang sahnya perkawinan, tata cara perkawinan, perjanjian perkawinan, pencegahan perkawinan, dan pembatalan perkawinan tetap diatur dalam Undang-Undang Perkawinan. Dengan demikian, UU Perkawinan adalah ketentuan umum, sedangkan PP Izin Perkawinan Dan Perceraian Bagi Pegawai Negeri Sipil dan Surat Surat Edaran Nomor 48/SE/1990 adalah PP Izin Perkawinan Dan Perceraian Bagi Pegawai Negeri Sipil merupakan ketentuan khusus.

Dalam Surat Edaran Nomor 48/SE/1990 disebutkan alasan-alasan Pegawai Negeri Sipil untuk melakukan perceraian adalah sebagai berikut:

1. Salah satu pihak berbuat zinah;

2. Salah satu pihak menjadi pemabok, pemadat, atau penjudi yang sukar disembuhkan;

3. Salah satu pihak meninggalkan pihak lain selama 2 (dua) tahun berturut-turut tanpa izin pihak lain dan tanpa alasan yang sah atau karena hal lain di luar kemampuan/kemauannya;

4. Salah satu pihak mendapat hukuman penjara 5 (lima) tahun atau hukuman yang lebih berat secara terus menerus setelah perkawinan berlangsung;

5. Salah satu pihak melakukan kekejaman atau penganiayaan berat yang membahayakan pihak lain.

Sebagai unsur aparatur negara, abdi negara, dan abdi masyarakat Pegawai Negeri Sipil dalam melaksanakan tugasnya diharapkan tidak terganggu oleh urusan kehidupan rumah tangga atau keluarganya. Dalam konteksnya terhadap nafkah mantan istri Pegawai Negeri Sipil, bahwa Pegawai Negeri Sipil sebagai unsur aparatur negara, abdi negara, dan abdi masyarakat diharapkan dapat menjadi teladan yang baik bagi masyarakat dalam tingkah laku, tindakan, dan ketaatan kepada peraturan perundang-undangan yang berlaku. Pegawai Negeri Sipil harus mentaati kewajiban tertentu dalam hal hendak bermaksud melakukan perceraian.

Pegawai Negeri Sipil yang melakukan perceraian mempunyai tambahan akibat hukum, yaitu pembagian gaji. Pembagian gaji tersebut sebagai bentuk perlindungan kepada bekas istri dan anak yang diharapkan dapat lebih menjamin keadilan bagi kedua belah pihak.8 PP Izin Perkawinan dan Perceraian mengatur kewajiban bagi Pegawai Negeri Sipil (Pria) yang menceraikan istrinya untuk memberikan biaya penghidupan bagi anak dan mantan isterinya. Hal ini sebagaimana ketentuan dalam Pasal 8 PP Izin Perkawinan Dan Perceraian bagi Pegawai Negeri Sipil yang mengatur sebagai berikut:

1. Apabila perceraian terjadi atas kehendak Pegawai Negeri Sipil maka ia wajib menyerahkan sebagian gajinya untuk penghidupan bekas istri dan anak-anaknya.

2. Pembagian gaji sebagaimana dimaksud dalam ayat 1 ialah sepertiga untuk Pegawai Negeri Sipil pria yang bersangkutan, sepertiga untuk bekas istrinya, dan sepertiga untuk anak atau anak-anaknya.

3. Apabila dari perkawinan tersebut tidak ada anak maka bagian gaji yang wajib diserahkan oleh Pegawai Negeri Sipil pria kepada bekas istrinya ialah setengah dari gajinya.

4. Apabila perceraian terjadi atas kehendak istri, maka ia tidak berhak atas bagian penghasilan dari bekas suaminya.

5. Ketentuan sebagaimana dimaksud dalam ayat (4) tidak berlaku, apabila istri meminta cerai karena dimadu.

6. Apabila bekas istri Pegawai Negeri Sipil yang bersangkutan kawin lagi, maka haknya atas bagian gaji dari bekas suaminya menjadi hapus terhitung mulai ia kawin lagi. 
Bagi Pegawai Negeri Sipil (pria) yang bercerai perihal kewajiban menyerahkan sebagian gajinya untuk biaya penghidupan kepada mantan istri dan anak pasca perceraian telah diatur dalam Pasal 8 ayat (1) PP Izin Perkawinan Dan Perceraian Bagi Pegawai Negeri Sipil. Jadi kewajiban untuk menyerahkan sebagian gaji tersebut hanya timbul apabila perceraian adalah atas kehendak Pegawai Negeri Sipil (pria/suami). Kewajiban yang ditentukan oleh Pasal 8 ayat (1) ini merupakan bentuk perlindungan hukum terhadap hak mantan istri dan anak-anak setelah terjadinya perceraian yang dikehendaki oleh Pegawai Negeri Sipil (pria).

Kewajiban menyerahkan sebagian gajinya untuk biaya penghidupan kepada mantan istri pasca perceraian tidak berlaku apabila perceraian terjadi atas kehendak istri (Pasal 8 ayat (4) PP Izin Perkawinan Dan Perceraian Bagi Pegawai Negeri Sipil). Namun Pasal 8 ayat (4) tidak berlaku apabila istri meminta cerai karena dimadu, hal ini sesuai dengan ketentuan Pasal 8 ayat (5) PP Izin Perkawinan Dan Perceraian Bagi Pegawai Negeri Sipil

Surat Edaran BKN Nomor 48 Tahun 1990 pada Bagian II angka 16 memberikan pengaturan yang lebih luas mengenai hak istri atas biaya penghidupan meskipun perceraian merupakan atas kehendak istri. Bagian II angka 16 mengatur sebagai berikut:

"Meskipun perceraian terjadi atas kehendak istri yang bersangkutan, haknya atas bagian gaji untuk bekas istri tetap diberikan apabila ternyata alasan istri mengajukan gugatan cerai karena dimadu, dan atau karena suami terbukti telah berzina, dan atau suami terbukti telah melakukan kekejaman atau penganiayaan berat baik lahir maupun batin terhadap istri, dan atau suami terbukti telah menjadi pemabuk, pemadat, dan penjudi yang sukar disembuhkan dan atau suami terbukti telah meninggalkan istri selama dua tahun berturut-turut tanpa ijin istri dan tanpa alasan yang sah atau karena hal lain di luar kemampuannya."

Berdasarkan ketentuan-ketentuan di atas, maka dapat disimpulkan hak mantan istri dan anak dari Pegawai Negeri Sipil (pria) pasca perceraian adalah sebagai berikut:

1. $1 / 3$ (sepertiga) untuk Pegawai Negeri Sipil (pria) yang bersangkutan, $1 / 3$ (sepertiga) untuk mantan istrinya, dan $1 / 3$ (sepertiga) untuk anak atau anak anaknya;

2. Apabila dari perkawinan tersebut tidak ada anak maka bagian gaji yang wajib diserahkan oleh PNS pria kepada bekas istrinya ialah $1 / 2$ (setengah) dari gajinya;

3. Apabila bekas istri PNS yang bersangkutan kawin lagi, maka haknya atas bagian gaji dari bekas suaminya menjadi hapus terhitung mulai ia kawin lagi.

Pengertian gaji dalam Surat Edaran BKN Nomor 48 Tahun 1990 dapat dilihat pada Bagian II angka 17 yang menyebutkan yang dimaksud dengan gaji adalah penghasilan yang diterima oleh suami dan tidak terbatas pada penghasilan suami pada waktu terjadinya perceraian.

Peraturan-peraturan a quo telah mengatur secara tegas perihal hak-hak istri dan anak (-anak) atas gaji Pegawai Negeri Sipil (pria) pasca perceraian. Namun kenyataan di lapangan tidaklah berjalan sesuai dengan ketentuan yang berlaku seperti kasus yang Penulis temukan sebagaimana dalam perkara pada Pengadilan Negeri Jakarta Pusat dengan Register Nomor: XX/Pdt.G/2020/PN.Jkt.Pst. Pasca diputuskannya perceraian antara AA dan BB yang mana dalam putusan tersebut mewajibkan AA untuk memberikan biaya penghidupan kepada mantan istri (BB) dan anaknya (CC) setiap bulannya sebesar Rp. 4.133 .300 (empat juta seratus tiga puluh tiga ribu tiga ratus rupiah), namun AA tidak menjalankan kewajibannya biaya penghidupan kepada mantan istri dan anaknya sebesar yang telah diputuskan pengadilan. AA merasa nominal sebagaimana yang diputuskan pada amar putusan terlalu besar sehingga dikhawatirkan tidak cukup untuk memenuhi kebutuhan hidupnya.

Meskipun telah diputuskan oleh Pengadilan, namun pengadilan tidak memiliki kekuasaan/kewenangan untuk memerintahkan suatu intansi untuk melaksanakan putusan perihal pembagian gaji pasca perceraian Pegawai Negeri Sipil. Hal tersebut dapat dilihat pada seperti pada Putusan Hakim Pengadilan Agama Semarang yang memutus perkara dengan Nomor 405/Pdt.G/2005/PA.Sm yang inti pertimbangannya menyatakan bahwa 
Majelis Hakim berpendapat bahwa masalah pembagian gaji tersebut adalah merupakan kewenangan instansi dimana pemohon bekerja dan Majelis menyerahkan sepenuhya masalah ini kepada instansi tersebut untuk menyelesaikannya.

Terkait kewenangan instansi terkait pembagian gaji pasca perceraian Pegawai Negeri Sipil (pria) telah diatur dalam ketentuan Surat Edaran BKN Nomor 48 Tahun 1990. Bagian II angka 18 dan 19 Surat Edaran BKN Nomor 48 Tahun 1990 mengatur sebagai berikut:

18) Bendaharawan gaji wajib menyerakan secara langsung bagian gaji yang menjadi hak bekas istri dan anak-anaknya sebagai akibat perceraian, tanpa lebih dahulu menunggu pengambilan gaji dari Pegawai Negeri Sipil bekas suami yang telah menceraikannya.

19) Bekas istri dapat mengambil bagian gaji yang menjadi haknya secara langsung dari Bendaharawan gaji, atau dengan surat kuasa, atau dapat meminta untuk dikirimkan kepadanya.

Dari ketentuan di atas maka pada saat akta cerai sudah diterima oleh instansi. Maka pihak instansi akan langsung memberikan kepada bendaharawan gaji. Bendaharawan wajib menyerahkan pembagian gaji tersebut kepada bekas istri. Bendaharawan dapat menyerahkan bagian gaji kepada bekas istri tanpa terlebih dahulu menunggu bekas suami untuk melakukan pengambilan gaji.

Pembagian gaji Pegawai Negeri Sipil setelah perceraian yang terikat dengan kedisiplinan pegawai, bendahara Instansi tempat mantan suami bekerja harus memeriksa hal-hal seperti apakah pembagian gaji setelah perceraian seperti yang dimaksud sesuai dengan perhitungan yang diatur dalam PP Izin Perkawinan dan Perceraian PNS dan/atau uang pembagian gaji benar sampai ke tangan mantan isteri serta anak Pegawai Negeri Sipil tersebut. Dengan demikian, hak mantan istri yang diceraikan dan anak-anak dapat terpenuhi. Apabila tidak tersampaikannya hak tersebut, bendahara instansi tempat mantan suami bekerja agar lebih bijaksana untuk menegur mantan suami tersebut atau memotong otomatis gaji tersebut dan secara langsung lalu diberikan kepada mantan istri dan anak-anaknya tanpa perantara dari mantan suaminya.

Dengan adanya Surat Edaran BKN Nomor 48 Tahun 1990 sebagaimana yang diatru dalam Bagian II angka 18 dan 19 maka upaya yang dapat dilakukan Pejabat (Atasan) dari instansi tempat Pegawai Negeri Sipil (pria) bekerja atas tuntutan dari mantan istri guna pemenuhan putusan pengadilan adalah dengan memerintahkan kepada Bendahara instansi untuk melakukan pembagian gaji Pegawai Negeri Sipil (pria) bersangkutan sesuai dengan putusan pengadilan. Selanjutnya bendahara instansi dapat memberikan pembagian gaji yang menjadi hak mantan istri dan anaknya kepada mantan istri atau yang dikuasakannya secara langsung. Selain pemberian secara langsung, dapat pula dengan memakai sistem auto debet dari rekening Pegawai Negeri Sipil (pria) ke rekening mantan istri.

Apabila upaya administratif tidak memberikan hasil positif, mantan istri dapat melakukan upaya perdata dengan melakukan upaya permohonan eksekusi ke pengadilan. Eksekusi sendiri yaitu menjalankan putusan pengadilan yang sudah berkekuatan hukum tetap. Putusan pengadilan yang dieksekusi adalah putusan pengadilan yang mengandung perintah kepada salah satu pihak untuk membayar sejumlah uang, atau menghukum pihak yang kalah untuk membayar sejumlah uang, atau juga pelaksanaan putusan hakim yang memerintahkan pengosongan benda tetap, sedangkan pihak yang kalah tidak mati melaksanakan putusan itu secara sukarela sehingga memerlukan upaya paksa dari pengadilan untuk melaksanakannya. Apabila pihak yang dikalahkan tidak mau melaksanakan isi utusan secara sukarela, maka pihak yang menang dapat mengajukan permohonan eksekusi kepada Pengadilan yang memutus perkara. Untuk pembahasan terkait upaya eksekusi dalam Penelitian ini tidak akan dibahas secara lebih lanjut dikarenakan fokus dalam Penelitian ini adalah terkait upaya-upaya administratif.

Pada contoh kasus yang Penulis teliti, BB dirinya telah melaporkan AA ke pejabat (atasan) dari instansi tempat AA bekerja terkait perilaku AA yang tidak memenuhi putusan 
pasca pengadilan dan meminta agar gaji smantan suaminya dipotong sesuai haknya dan anaknya dan dikirim ke rekeningnya. Atas laporan tersebut Biro Kepatuhan Internal dan Biro Kepegawaian memproses laporan terhadap AA dan membawa AA ke bank rekanan pencairan gaji untuk melakukan auto debet gaji AA ke BB setiap bulannya, namun nominalnya tidak sesuai dengan yang tercantum di amar putusan yaitu Rp. 4.133.300 (empat juta seratus tiga puluh tiga ribu tiga ratus rupiah) dikarenakan AA keberatan dengan nominal tersebut.

PP Izin Perkawinan dan Perceraian bagi Pegawai Negeri Sipil dan Surat Edaran BKN Nomor 48 Tahun 1990 telah mengatur apabila Pegawai Negeri Sipil menolak melaksanakan kewajiban pembagian gaji pasca perceraiaan atau tidak melaporkan perceraiannya kepada Pejabat dalam jangka waktu selambat-lambatnya satu bulan setelah terjadinya perceraian, maka bagi Pegawai Negeri Sipil yang bersangkutan dapat dikenakan sanksi hukuman disiplin berat.

Apabila terdapat Pegawai Negeri Sipil yang tidak melaksanakan putusan Pengadilan atau tidak melaporkan perceraiannya, maka Pejabat (atasan) dari Pegawai Negeri Sipil yang bekerja pada instansi terkait haruslah melakukan tindakan tegas dengan cara melakukan teguran kepada Pegawai Negeri Sipil terkait untuk mentaati keputusan Pengadilan terkait percerainnya. Jika teguran Pejabat (atasan) tidak ditanggapi, maka Pejabat (atasan) dapat melakukan proses pemberian sanksi kepada Pegawai Negeri Sipil bersangkutan berupa hukuman displin berat sebagaimana yang diatur dalam PP Izin Perkawinan dan Perceraian dan Surat Edaran BKN Nomor 48 Tahun 1990. Peran aktif Pejabat (atasan) ini diperlukan agar dapat memberikan perlindungan hukum terhadap hak anak dan mantan isteri setelah perceraian tersebut.

Apabila ditemukan kasus perceraian Pegawai Negeri Sipil yang dalam putusan perceraiannya tidak disebutkan mengenai pembagian gaji untuk mantan istri dan anak. Apabila Pejabat (atasan) dari tempat Pegawai Negeri Sipil (pria) bekerja menerima permohonan/laporan dari mantan istri maka Pejabat (atasan) tersebut tetap dapat menindaklanjuti permohonan/laporan tersebut. Tindakan ini menurut Penulis adalah bentuk dikresi dari Pejabat (atasan) yang bersangkutan, yaitu sebagai salah satu sarana yang memberikan ruang bergerak bagi pejabat atau badan-badan administrasi negara untuk melakukan tindankan tanpa harus terikat sepenuhnya pada undang-undang, atau tindakan yang dilakukan dengan mengutamakan pencapaian tujuan (doelmatigheid) daripada sesuai dengan hukum yang berlaku (rechtmatigheid). Dalam Undang-Undang Nomor 11 Tahun 2020 tentang Cipta Kerja (selanjutnya UU Cipta Kerja) memberikan pengertian diskresi sebagai keputusan dan/atau tindakan yang ditetapkan dan/atau dilakukan oleh Pejabat Pemerintahan untuk mengatasi persoalan konkret yang dihadapi dalam penyelenggaraan pemerintahan dalam hal peraturan perundang-undangan yang memberikan pilihan, tidak mengatur, tidak lengkap atau tidak jelas, dan/atau adanya stagnasi pemerintahan.

Tujuan dari diskresi antara lain

1. melancarkan penyelenggaraan pemerintahan;

2. mengisi kekosongan hukum;

3. memberikan kepastian hukum; dan

4. mengatasi stagnasi pemerintahan dalam keadaan tertentu guna kemanfaatan dan kepentingan umum.

Berdasarkan hal-hal di atas maka diskresi dari pejabat (atasan) untuk memproses permohonan/laporan dari mantan istri atas perceraian Pegawai Negeri Sipil (pria) yang dalam putusan perceraiannya tidak disebutkan mengenai pembagian gaji untuk mantan istri dan anak dapat dilakukan untuk yang mana diskresi tersebut bertujuan untuk memberikan kepastian hukum dan perlindungan hukum untuk mantan istri dan anak pasca perceraian.

Kehidupan sosial dalam masyarakat umum yang menganggap pekerjaan Pegawai Negeri Sipil merupakan pekerjaan yang dimuliakan dan dianggap suatu golongan khusus berbeda dengan masyarakat pada umumnya, dan dianggap harus bisa menjadi contoh yang 
baik sebagai kalangan orang-orang yang dengan otomatis dijamin kehidupannya oleh Negara. Setiap langkah dari segi kehidupannya terikat dengan semua peraturan yang berujung kepada ketertiban, karena hidup dan keluarganya pun dijamin oleh Negara.

Adanya peraturan $a$ quo tentang pembagian gaji setelah perceraian bagi Pegawai Negeri Sipil diharapkan dapat menertibkan golongan Pegawai Negeri Sipil yang dianggap mulia agar tidak sembarangan dalam bertindak serta mematuhi peraturan perundangundagan yang sudah ditetapkan untuk memenuhi kewajibannya sebagai Pegawai Negeri Sipil setelah perceraian yang harus membagi gajinya sepertiga untuk mantan istri selama mantan istri belum menikah lagi dan sepertiga lagi untuk nafkah anak.

\subsection{Penegakan Disiplin Bagi PNS Yang Tidak Melaksanakan Putusan Pengadilan Terkait Biaya Penghidupan Anak Dan Mantan Istri Akibat Perceraian}

Pegawai Negeri Sipil adalah warga negara Indonesia yang memenuhi syarat tertentu, diangkat sebagai pegawai Aparatur Sipil Negara secara tetap oleh pejabat pembina kepegawaian untuk menduduki jabatan pemerintahan. Pegawai Negeri Sipil merupakan salah satu unsur penting dalam penyelenggaraan roda pemerintah yang keberadaannya sesuai dengan keputusan dari pemerintah. Menyadari peranan Pegawai Negeri Sipil yang demikian pentingnya, maka pemerintah memberikan beberapa hak tertentu kepada Pegawai Negeri Sipil, antara lain hak atas gaji, hak atas cuti, dan hak atas pensiun.

Pegawai Negeri Sipil merupakan unsur aparatur negara wajib memberikan contoh yang baik kepada bawahannya dan menjadi teladan sebagai warga negara yang baik dalam masyarakat, abdi negara dan abdi masyarakat yang juga harus menjadi teladan dalam tingkah laku, tindakan dan ketaatan kepada peraturan perundang-undangan yang berlaku, untuk dapat melaksanakan kewajiban yang demikian itu, maka kehidupan Pegawai Negeri Sipil harus ditunjang oleh kehidupan berkeluarga yang serasi, sehingga setiap Pegawai Negeri Sipil dalam melaksanakan tugasnya tidak akan banyak terganggu oleh masalah-masalah dalam keluarganya.

Pasal 2 Undang Undang-Undang Nomor 5 Tahun 2014 tentang Aparatur Sipil Negara (selanjutnya disebut UU Aparatur Sipil Negara) menyebutkan bahwa terhadap kebijakan dan Manajemen Aparatur Sipil Negara berlandaskan pada asas:

1. Kepastian Hukum

Yang dimaksud dengan "asas kepastian hukum" adalah dalam setiap penyelenggaraan kebijakan dan Manajemen Aparatur Sipil Negara, mengutamakan landasan peraturan perundang-undangan, kepatutan, dan keadilan.

2. Profesionalitas

Yang dimaksud dengan "asas profesionalitas" adalah mengutamakan keahlian yang berlandaskan kode etik dan ketentuan peraturan perundang-undangan.

3. Proporsionalitas

Yang dimaksud dengan "asas proporsionalitas" adalah mengutamakan keseimbangan antara hak dan kewajiban Pegawai Aparatur Sipil Negara.

4. Keterpaduan

Yang dimaksud dengan "asas keterpaduan" adalah pengelolaan Pegawai Aparatur Sipil Negara didasarkan pada satu sistem pengelolaan yang terpadu secara nasional.

5. Delegasi

Yang dimaksud dengan "asas delegasi" adalah bahwa sebagian kewenangan pengelolaan Pegawai Aparatur Sipil Negara dapat didelegasikan pelaksanaannya kepada kementerian, lembaga pemerintah nonkementerian, dan pemerintah daerah.

6. Netralitas

Yang dimaksud dengan "asas netralitas" adalah bahwa setiap Pegawai Aparatur Sipil Negara tidak berpihak dari segala bentuk pengaruh manapun dan tidak memihak kepada kepentingan siapapun.

7. Akuntabilitas. 
Yang dimaksud dengan "asas akuntabilitas" adalah bahwa setiap kegiatan dan hasil akhir dari kegiatan Pegawai Aparatur Sipil Negara harus dapat dipertanggungjawabkan kepada masyarakat sesuai dengan ketentuan peraturan perundang-undangan.

8. Efektif Dan Efisien.

Yang dimaksud dengan "asas efektif dan efisien" adalah bahwa dalam menyelenggarakan Manajemen Aparatur Sipil Negara sesuai dengan target atau tujuan dengan tepat waktu sesuai dengan perencanaan yang ditetapkan.

9. Keterbukaan

Yang dimaksud dengan "asas keterbukaan" adalah bahwa dalam penyelenggaraan Manajemen Aparatur Sipil Negara bersifat terbuka untuk publik.

10. Nondiskriminatif

Yang dimaksud dengan "asas nondiskriminatif" adalah bahwa dalam penyelenggaraan Manajemen Aparatur Sipil Negara, Aparatur Sipil Negara tidak membedakan perlakuan berdasarkan jender, suku, agama, ras, dan golongan.

11. Persatuan dan Kesatuan

Yang dimaksud dengan "asas persatuan dan kesatuan" adalah bahwa Pegawai Aparatur Sipil Negara sebagai perekat Negara Kesatuan Republik Indonesia.

12. Keadilan dan Kesetaraan

Yang dimaksud dengan "asas keadilan dan kesetaraan" adalah bahwa pengaturan penyelenggaraan Aparatur Sipil Negara harus mencerminkan rasa keadilan dan kesamaan untuk memperoleh kesempatan akan fungsi dan peran sebagai Pegawai Aparatur Sipil Negara.

13. Kesejahteraan

Yang dimaksud dengan "asas kesejahteraan" adalah bahwa penyelenggaraan Aparatur Sipil Negara diarahkan untuk mewujudkan peningkatan kualitas hidup Pegawai Aparatur Sipil Negara.

Pegawai Negeri Sipil sebagai unsur aparatur negara, abdi negara dan abdi masyarakat yang penuh dengan kesetiaan dan ketaatan kepada Pancasila, UUD 1945, Negara dan Pemerintah menyelenggarakan tugas pemerintahan dan pembangunan. Sehubungan dengan kedudukan Pegawai Negeri Sipil maka baginya dibebankan kewajiban-kewajiban yang harus dilaksanakan dan sudah tentu di samping kewajiban juga diberikan apa-apa saja yang menjadi hak yang didapat oleh seorang Pegawai Negeri Sipil.

Kedisiplinan adalah salah satu faktor yang penting dalam suatu organisasi. Dikatakan sebagai faktor yang penting karena disiplin akan mempengaruhi kinerja pegawaidalam suatu organisasi. Semakin tinggi disiplin pegawai semakin tinggi pula prestasi kerja yang dapat dicapai. Disiplin adalah merupakan cerminan besarnya tanggungjawab seseorang dalam melakukan tugas-tugas yang diberikan kepadanya yang mendorong gairah dan semangat kerja seseorang. Pada umumnya disiplin yang baik apabila pegawai datang ke kantor dengan teratur dan tepat waktu, dengan berpakaian serba baik dan rapih pada tempat bekerjanya. Mereka menggunakan bahan-bahan dan perlengkapan dengan hati-hati. Mereka menghasilkan jumlah dan kualitas pekerjaanyang memuaskan dan mengikuti cara kerja yang ditentukan oleh organisasi dan menyelesaikan dengan sangat baik.

PP Disiplin Pegawai Negeri Sipil telah membatasi pergerakan Pegawai Negeri Sipil untuk berbuat sewenang-wenang demi menjaga ketertiban dan kedisiplinan Pegawai Negeri Sipil sebagai contoh bagi masyarakat. Pengertian Disiplin Pegawai Negeri Sipil di dalam PP Disiplin Pegawai Negeri Sipil pada Pasal 1 angka 1 yaitu:

"Disiplin Pegawai Negeri Sipil adalah kesanggupan Pegawai Negeri Sipil untuk menaati kewajiban dan menghindari larangan yang ditentukan dalam peraturan perundang-undangan dan/atau peraturan kedinasan yang apabila tidak ditaati atau dilanggar dijatuhi hukuman disiplin."

Sanksi bagi Pegawai Negeri Sipil yang melanggar peraturan perundang-undangan dan/atau peraturan kedinasan diatur pada Pasal 6 PP Disiplin Pegawai Negeri Sipil yang 
mengatur bahwa dengan tidak mengesampingkan ketentuan dalam peraturan perundangundangan pidana, Pegawai Negeri Sipil yang melakukan pelangggaran disiplin dijatuhi hukuman disiplin.

Hukuman disiplin adalah hukuman yang dijatuhkan kepada Pegawai Negeri Sipil karena melanggar Peraturan Disiplin Pegawai Negeri Sipil. Selanjutnya dalam Pasal 5 PP Disiplin Pegawai Negeri Sipil didefenisikan pelanggaran disiplin yaitu setiap ucapan, tulisan, atau Perbuatan Pegawai Negeri Sipil yang tidak menaati kewajiban atau melanggar ketentuan disiplin Pegawai Negeri Sipil, baik yang dilakukan didalam maupun diluar jam kerja. Dalam PP Disiplin Pegawai Negeri Sipil juga telah diatur mengenai kewajiban Pegawai Negeri Sipil dan jenis hukuman disiplin.

Tingkat dan jenis hukuman disiplin menurut Pasal 7 PP Disiplin Pegawai Negeri Sipil adalah sebagai berikut:

1. Tingkat hukuman disiplin terdiri dari:

a) Hukuman disiplin ringan;

b) Hukuman disiplin sedang;

c) Hukuman disiplin berat.

2. Jenis hukuman disiplin ringan sebagaiman dimaksud pada ayat (1) huruf a di atas terdiri dari:

a) Teguran lisan;

b) Teguran tertulis;

c) Pernyataan tidak puas secara tertulis.

3. Jenis hukuman disiplin sedang sebagaimana dimaksud pada ayat (1) huruf b terdiri dari:

a) Penundaaan kenaikan gaji berkala selama 1 (satu) tahun;

b) Penundaan kenaikan pangkat selama 1 (satu) tahun;

c) Penurunan pangkat setingkat lebih rendah selama 1(satu) tahun.

4. Jenis hukuman disiplin berat sebagaimana dimaksud pada ayat (1) huruf c terdiri dari:

a) Penurunan pangkat setingkat lebih rendah selama 3 (tiga) tahun;

b) Pemindahan dalam rangka penurunan jabatan setingkat lebih rendah;

c) Pembebasan dari jabatan;

d) Pemberhentian dengan tidak hormat tidak atas permintaan sendiri sebagai PNS; dan

e) Pemberhentian tidak dengan hormat sebagai PNS.

Disiplin Pegawai Negeri Sipil adalah kesanggupan Pegawai Negeri Sipil untuk mentaati kewajiban dan menghindari larangan yang ditentukan dalam peraturan perundangundangan dan/atau peraturan kedinasan yang apabila tidak ditaati, dilanggar, dijatuhi hukuman disiplin.

Pegawai Negeri Sipil harus menaati kewajiban tertentu dalam hal hendak melangsungkan perkawinan, beristri lebih dari satu, dan atau bermaksud melakukan perceraian. Mengenai hak bekas isteri dan anak dari Pegawai Negeri Sipil (pria) pasca perceraian dapat dilihat dalam Pasal 8 ayat (1) PP Izin Perkawinan Dan Perceraian Bagi Pegawai Negeri Sipil yang menyatakan: Apabila perceraian terjadi atas kehendak Pegawai Negeri Sipil (pria) maka ia wajib menyerahkan sebagian gajinya untuk penghidupan bekas isteri dan anak- anaknya. Jadi kewajiban untuk menyerahkan sebagian gaji tersebut hanya timbul apabila perceraian adalah atas kehendak suami. Mengenai pembagian gaji Pegawai Negeri Sipil (pria) suami tersebut diatur dalam Pasal 8 ayat (10) PP Izin Perkawinan Dan Perceraian Bagi Pegawai Negeri Sipil yang dapat dilihat pada pembahasan sebelumnya.

Peraturan-peraturan a quo secara tegas telah mengatur kewajiban bagi Pegawai Negeri Sipil (pria) apabila bercerai untuk memberikan biaya penghidupan kepada anak dan mantan isterinya. Namun kenyataannya terdapat hambatan-hambatan dalam pelaksanaan kewajiban tersebut, diantaranya:

1. Keadaan ekonomi yang mengakibatkan bekas suami tidak dapat melaksanakan kewajibannya pasca perceraian; 
2. Bekas istri dan anaknya tidak menuntut hak pembagian gaji pasca perceraian tersebut;

3. Pegawai Negeri Sipil (pria) yang telah menghabiskan penghasilannya yang mengakibatkan tidak dapat terpenuhinya kewajiban untuk melakukan pembagian gaji terhadap mantan istri dan anaknya (gajinya minus).

4. Ketidaksadaran dari Pegawai Negeri Sipil (pria) tersebut karena tidak mengetahui adanya ketentuan mengenai pembagian gaji pasca perceraian.

Dalam PP Izin Perkawinan Dan Perceraian Bagi Pegawai Negeri Sipil tidak diatur alasan pengecualian/pembenar bagi Pegawai Negeri Sipil (pria) untuk tidak memenuhi kewajibannya pasca perceraian, misalnya karena gaji yang diterimanya menjadi berkurang untuk keberlangsungan hidupnya. Bahkan Pasal 16 PP Izin Perkawinan Dan Perceraian Bagi Pegawai Negeri Sipil secara tegas telah mengatur sanksi bagi Pegawai Negeri Sipil yang menolak melaksanakan ketentuan pembagian gaji. Pasal 16 PP Izin Perkawinan Dan Perceraian Bagi Pegawai Negeri Sipil mengatur sebagai berikut:

"Pegawai Negeri Sipil yang menolak melaksanakan ketentuan pembagian gaji sesuai dengan ketentuan Pasal 8, dijatuhi salah satu hukuman disiplin berat berdasarkan PP Disiplin PNS."

Ketentuan Pasal 16 di atas kembali dipertegas dalam dengan Surat Edaran No.48/SE/1990 di Bab VIII mengenai sanksi dimana angka 3 mengatur:

"Pegawai Negeri Sipil, kecuali pegawai bulanan disamping pensiun, dijatuhi salah satu hukuman disiplin berat berdasarkan PP Disiplin PNS, apabila menolak melaksanakan pembagian gaji dan atau tidak mau menandatangani daftar gajinya sebagai akibat dari perceraian."

Jenis hukuman disiplin berat sebagaimana dimaksud pada PP Disiplin Pegawai Negeri Sipil terdiri dari:

1. Penurunan pangkat setingkat lebih rendah selama 3 (tiga) tahun;

2. Pemindahan dalam rangka penurunan jabatan setingkat lebih rendah;

3. Pembebasan dari jabatan;

4. Pemberhentian dengan tidak hormat tidak atas permintaan sendiri sebagai PNS; dan

5. Pemberhentian tidak dengan hormat sebagai PNS.

Tekait dengan penetapan hukuman disiplin, kategori pejabat yang berwenang memberikan hukuman dikategorikan sebagai berikut:

1. Presiden berwenang menetapkan hukuman disiplin bagi Pejabat Eselon I dan jabatan lain yang pengangkatan dan pemberhentiannya menjadi wewenang presiden;

2. Pejabat Pembina Kepegawaian berwenang menjatuhkan hukuman disiplin kepada Eselon I, Eselon II, Eselon III, Eselon IV, serta para pejabat fungsional dan jabatan fungsional umum, mulai dari hukuman ringan sampai hukuman berat;

3. Untuk Pejabat Eselon I, Eselon II, Eselon III, Eselon IV, Eselon V, berlaku rumus:

a) One Step Down untuk jenis hukuman ringan. Misalnya Pejabat Eselon I menjatuhkan hukuman-hukuman tingkat ringan bagi Eselon II, III, dan seterusnya;

b) Two Step Down untuk jenis hukuman sedang. Misalnya Eselon I menjatuhkan hukuman tingkat sedang bagi Eselon III, IV, dan seterusnya.

Suami tidak dapat menolak untuk memberikan pembagian gaji, karena sesuai dengan peraturan yang ada bahwa Pegawai Negeri Sipil (pria) yang menceraikan istrinya wajib melakukan pembagian gaji. Sehingga jika PNS pria tersebut menolak maka pihak Badan Kepegawaian, Pendidikan dan Pelatihan (BKPP) atau instansi yang terkait dapat memberikan surat teguran kepada Pegawai Negeri Sipil (pria) yang bersangkutan atau hingga pemberian sanksi oleh pejabat yang berwenang berupa hukuman disiplin berat sebagaimana yang diatur dalam PP Disiplin Pegawai Negeri Sipil.

Selain karena dapat menolak untuk memberikan pembagian gaji, hukuman disiplin berat juga dapat diberikan kepada Pegawai Negeri Sipil karena tidak melaporkan perceraiannya kepada Pejabat. Bagian VIII angka 1 huruf e Surat Edaran BKN Nomor 48 Tahun 1990 mengatur bahwa Pegawai Negeri Sipil dan atau atasan/pejabat, kecuali pegawai 
bulanan disamping pensiun, dijatuhi salah satu hukuman disiplin berat berdasarkan PP Disiplin Pegawai Negeri Sipil, apabila melakukan perbuatan tidak melaporkan perceraiannya kepada Pejabat dalam jangka waktu selambat-lambatnya satu bulan setelah terjadinya perceraian.

Adanya kewajiban melaporkan kepada Pejabat (atasan) apabila terjadi perceraian tidak selalu dilaksanakan oleh Pegawai Negeri Sipil yang bersangkutan. Tidak dilaporkannya perceraian oleh Pegawai Negeri Sipil yang bersangkutan dapat menyebabkan tidak terpenuhinya hak anak dan mantan isteri setelah perceraian tersebut. Dalam kasus ini, kurangnya kepedulian seorang ayah terhadap masa depan anak-anak yang masih menjadi tanggung jawab penuh walaupun antara suami dan istri sudah bercerai.

Adanya ketentuan hukuman displin berat bagi Pegawai Negeri Sipil yang menolak melaksanakan pembagian gaji sebagai akibat dari perceraian dan/atau tidak melaporkan perceraiannya kepada Pejabat merupakan suatu bentuk perlindungan hukum terhadap hak anak dan mantan isteri pasca perceraian. Apabila Pegawai Negeri Sipil (pria) tidak memenuhi kewajibannya, maka bagi Pegawai Negeri Sipil selayaknya diberikan saksi sesuai dengan ketentuan perundangan-undangan yakni hukuman disiplin berat. Penegakan dispilin terhadap Pegawai Negeri Sipil perlu dilakukan agar dapat memberikan perlindungan hukum terhadao hak mantan istri dan anak serta terpenuhinya asas kepastian hukum yang terkandung dalam UU Aparatur Sipil Negara.

Peneliti menilai perlu adanya upaya sosialisasi dari Badan Kepegawaian, Pendidikan dan Pelatihan (BKPP) atau instansi terkait mengenai proses serta akibat-akibat hukum yang timbul apabila adanya perceraian yang dilakukan oleh Pegawai Negeri Sipil. Selain itu pemerintah daerah dapat menerbitkan Peraturan Daerah sebagai penegasan terhadap PP PP Izin Perkawinan Dan Perceraian Bagi Pegawai Negeri Sipil dan Surat Edaran No.48/SE/1990, dikarenakan aturan-aturan tersebut pemberlakuannya telah lama, maka Peneliti menilai perlu adanya aturan baru dalam bentuk Peraturan Daerah agar aturan tentang Perkawinan dan Perceraian bagi Pegawai Negeri Sipil dapat diketahui masyarakat pada umumnya, khususnya Pegawai Negeri Sipil, yang bertujuan untuk meningkatkan kepatuhan hukum terhadap ketentuan-ketentuan yang mengatur tentang Izin Perkawinan Dan Perceraian Bagi Pegawai Negeri Sipil serta kedepannya alasan tidak mengetahui aturan yang ada dapat diminimalisir.

\section{KESIMPULAN}

Dari uraian di atas, Penulis menarik kesimpulan sebagai berikut:

1. Upaya yang dapat dilakukan Pejabat (Atasan) dari instansi tempat Pegawai Negeri Sipil bekerja atas tuntutan dari mantan istri guna pemenuhan putusan pengadilan adalah dengan memerintahkan kepada Bendahara instansi untuk melakukan pembagian gaji Pegawai Negeri Sipil bersangkutan sesuai dengan putusan pengadilan. Selanjutnya bendahara instansi dapat memberikan pembagian gaji yang menjadi hak mantan istri dan anaknya kepada mantan istri atau yang dikuasakannya secara langsung. Selain pemberian secara langsung, dapat pula dengan memakai sistem auto debet dari rekening Pegawai Negeri Sipil ke rekening mantan istri. Pejabat (atasan) dari tempat Pegawai Negeri Sipil bekerja dapat melakukan diskresi apabila ditemukan kasus perceraian Pegawai Negeri Sipil yang dalam putusan perceraiannya tidak disebutkan mengenai pembagian gaji untuk mantan istri dan anak. Apabila Pejabat (atasan) dari tempat Pegawai Negeri Sipil bekerja menerima permohonan/laporan dari mantan istri maka Pejabat (atasan) tersebut tetap dapat menindaklanjuti permohonan/laporan tersebut.

2. Bagi Pejabat (Atasan) yang membawahi Pegawai Negeri Sipil pria yang bercerai namun tidak memberikan biaya penghidupan untuk mantan istri dan anaknya sesuai dengan putusan dapat memberikan sanksi salah satu hukuman disiplin berat berdasarkan Pasal 16 PP Izin Perkawinan dan Perceraian PNS jo. Surat Edaran No.48/SE/1990. Jenis hukuman disiplin berat yang diatur dalam PP Disiplin Pegawai Negeri Sipil adalah: a) Penurunan pangkat setingkat lebih rendah selama 3 tahun; b) Pemindahan dalam rangka penurunan jabatan setingkat lebih 
rendah; c) Pembebasan dari jabatan; d) Pemberhentian dengan tidak hormat tidak atas permintaan sendiri sebagai Pegawai Negeri Sipil; e) Pemberhentian tidak dengan hormat sebagai Pegawai Negeri Sipil. Hal tersebut menjadi kewajiban PNS pria yang bercerai karena telah diatur dalam Pasal 8 ayat (1) PP Izin Perkawinan dan Perceraian PNS yang menyabutkan bahwa tidak diatur alasan pengecualian/pembenar bagi Pegawai Negeri Sipil untuk tidak memenuhi kewajibannya pasca perceraian. Dalam hal kasus yang diangkat dalam penelitian ini, oleh karena Tergugat telah melaporkan Penggugat kepada Atasan Penggugat dan Biro Kepatuhan Internal, telah dilakukan Berita Acara Pemeriksaan (BAP) kepada Penggugat dan Tergugat dan sedang dilakukan pemeriksaan lebih lanjut terkait dasar penjatuhan sanksi.

\section{SARAN}

1. Dalam rangka terciptanya disiplin Pegawai, sebagai aparatur negara yang sudah seharusnya menjadi contoh tauladan di masyarakat maka dalam rangka menciptakan tertib administrasi bahwa Pegawai Negeri Sipil yang akan melakukan Perkawinan dan Perceraian sudah seharusnya mengetahui terlebih dahulu mengenai ketentuan-ketentuan yang berlaku khususnya mengenai peraturan tentang izin perkawinan dan perceraian dan mengenai peraturan kepegawaian pada umumnya. Apabila terdapat Pegawai Negeri Sipil yang tidak melaksanakan putusan Pengadilan, maka Pejabat (atasan) dari Pegawai Negeri Sipil yang bekerja pada instansi terkait haruslah berani bersikap tegas kepada Pegawai Negeri Sipil terkait untuk mentaati keputusan Pengadilan terkait percerainnya. Peran aktif Pejabat (atasan) ini diperlukan agar dapat memberikan perlindungan hukum terhadap hak anak dan mantan istri setelah perceraian tersebut.

2. Perlu adanya upaya sosialisasi dari Badan Kepegawaian, Pendidikan dan Pelatihan (BKPP) atau instansi terkait mengenai proses serta akibat-akibat hukum yang timbul apabila adanya perceraian yang dilakukan oleh Pegawai Negeri Sipil. Selain itu pemerintah daerah dapat menerbitkan Peraturan Daerah sebagai penegasan terhadap PP PP Izin Perkawinan dan Perceraian PNS dan Surat Edaran No. 48/SE/1990, dikarenakan aturan-aturan tersebut pemberlakuannya telah lama, maka Peneliti menilai perlu adanya aturan baru dalam bentuk Peraturan Daerah agar aturan tentang Perkawinan dan Perceraian bagi Pegawai Negeri Sipil dapat diketahui masyarakat pada umumnya, khususnya Pegawai Negeri Sipil, yang bertujuan untuk meningkatkan kepatuhan hukum terhadap ketentuan-ketentuan yang mengatur tentang Izin Perkawinan dan Perceraian Bagi Pegawai Negeri Sipil serta kedepannya alasan tidak mengetahui aturan yang ada dapat diminimalisir.

\section{DAFTAR PUSTAKA}

\section{Peraturan Perundang-Undangan}

Indonesia. Undang-Undang Dasar 1945, LN No. 75, BN No. 69 dan perubahannya. . Undang-Undang Perkawinan, Undang Undang Nomor 1 Tahun 1974, LN No. 1, TLN No. 3019.

. Undang-Undang Aparatur Sipil Negara, Undang Undang Nomor 5 Tahun 2014, LN No. 6, TLN No. 5494.

. Peraturan Pemerintah Tentang Izin Perkawinan Dan Perceraian Bagi Pegawai Negeri Sipil, Peraturan Pemerintah Nomor 10 Tahun 1983, LN No. 13, TLN No. 3250, . Peraturan Pemerintah Perubahan Atas Peraturan Pemerintah Nomor 10 Tahun 1983 Tentang Izin Perkawinan Dan Perceraian Bagi Pegawai Negeri Sipil, Peraturan Pemerintah Nomor 45 Tahun 1990, LN No. 61, TLN No. 3424,

. Peraturan Pemerintah Disiplin Pegawai Negeri Sipil, Peraturan Pemerintah Nomor 53 Tahun 2010, LN No. 74, TLN No. 5315,

Surat Edaran Nomor 48/SE/1990 tentang Petunjuk Pelaksanaan PP Izin Perkawinan dan Perceraian bagi Pegawai Negeri Sipil

\section{Buku}

Abdul Manan, Penerapan Hukum Acara Perdata di Lingkungan Peradilan Agama, (Jakarta: Kencana, 2006). 
Amiruddin, Pengantar Metode Penelitian Hukum, Jakarta: Raja Grafindo Persada, 2006.

H.M. Djamil Latif, Aneka Hukum Perceraian di Indonesia, (Jakarta: Ghalia Indonesia, 1985).

Harmon Harun, Himpunan UU Kepegawaian, (Jakarta: Raja Grafindo Persada, 2004).

Malayu Hasibuan, Manajemen Sumber Daya Manusia, (Jakarta: Bumi Aksara, 2003).

Marzuki, Metodologi Riset, Yogyakarta: Hanindita Offser, 1983.

Muchsin Bani Amin, Hukum Acara Peradilan Agama/Mahkamah Syareiyah, (Banda Aceh:

Percetakan Hijrah, 2016).

R. Subekti, Pokok-Pokok Hukum Perdata, (Jakarta: Intermasa, 2003).

Ridwan, Tiga Dimensi Hukum Administrasi dan Peradilan Administrasi, (Yogyakarta: FH UII Press, 2009).

Soerjono Soekanto dan Sri Mamudji, Penelitian Hukum Normatif (Suatu Tinjauan Singkat), Jakarta: Rajawali Perss, 2003.

Sudarsono, Hukum Perkawinan Nasional, (Jakarta: Renika Cipta, 1991).

Wahyono Darmabrata, Surini Ahlan Sjarif, Hukum Perkawinan dan Keluarga di Indonesia, (Jakarta: Badan Penerbit Fakultas Hukum Universitas Indonesia, 2004).

Syarifuddin, Muhammad, dkk. Hukum Perceraian, Jakarta: Sinar Grafika, 2014.

Wantjik Saleh, Hukum Perkawinan Indonesia, (Jakarta: Ghalia Indonesia,1980).

Wienarsih Imam Subekti dan Sri Soesilowati Mahdi, Hukum Perorangan dan Kekeluargaan Perdata Barat, (Jakarta: Gitama Jaya, 2005).

\section{Artikel/Makalah/Laporan Penelitian}

Mohammad Rafik, "Pelaksanaan Disiplin Pegawai Negeri Sipil (PNS) Di Lingkungan Kantor Kejaksaan Negeri Palu Sulawesi Tengah Berdasarkan Peraturan Pemerintah Nomor 53 Tahun 2010”, Jurnal Ilmu Hukum Legal Opinion, Edisi 2, Volume 4 (2016).

Muh. Jamal Jami, "Izin Perkawinan dan Perceraian bagi PNS (Suatu Analisi Hukum Islam Terhadap PP No 10/1983 jo. PP No 45/1990", Jurnal Al-Qadau, Volume 1 (2014).

Rina R. Novianti, "Penerapan Peraturan Pemerintah Nomor 45 Tahun 1990 Tentang Perubahan Atas Peraturan Pemerintah Nomor 10 Tahun 1983 Tentang Izin Perkawinan Dan Perceraian Pegawai Negeri Sipil Terhadap Proses Perceraian Pegawai Negeri Sipil”, Tesis, Fakultas Hukum Universitas Indonesia Program Magister Kenotariatan, Januari 2012.

Tri Wahyuni Herawati, dkk, "Perlindungan Hak Atas Pembagian Gaji Akibat Perceraian Yang Dilakukan Oleh Pegawai Negeri Sipil", Diponegoro Law Journal, Volume 6, Nomor 2 (2017). 